\title{
South African universities in a time of increasing disruption
}

\begin{tabular}{|c|c|}
\hline $\begin{array}{l}\text { Authors: } \\
\text { Johan Coetze } \\
\text { Brownhilder } \\
\text { Karlien Stemn } \\
\text { Jana Lamprec } \\
\text { Constance Mo } \\
\text { Winnie Seree }\end{array}$ & $\begin{array}{l}{ }^{1} \text { (D) } \\
\text { eneh }{ }^{2} \text { (D) } \\
\mathrm{et}^{1} \text { (D) } \\
\mathrm{tt}^{3} \text { (D) } \\
\mathrm{tsitsi}^{4} \text { (D) } \\
\mathrm{o}^{2} \text { (1) }\end{array}$ \\
\hline $\begin{array}{l}\text { Affiliations: } \\
{ }^{1} \text { Department } \\
\text { and Finance, } \\
\text { the Free State } \\
\text { South Africa }\end{array}$ & $\begin{array}{l}\text { Economics } \\
\text { Iniversity of } \\
\text { Bloemfontein, }\end{array}$ \\
\hline $\begin{array}{l}{ }^{2} \text { Department } \\
\text { Management, } \\
\text { Economic and } \\
\text { Sciences, Univ } \\
\text { Free State, Blo } \\
\text { South Africa }\end{array}$ & $\begin{array}{l}\text { f Business } \\
\text { Faculty of } \\
\text { Management } \\
\text { ersity of the } \\
\text { emfontein, }\end{array}$ \\
\hline $\begin{array}{l}{ }^{3} \text { School of Acc } \\
\text { Faculty of Eco } \\
\text { Management } \\
\text { University of } \\
\text { Bloemfontein, }\end{array}$ & $\begin{array}{l}\text { ountancy, } \\
\text { lomic and } \\
\text { Sciences, } \\
\text { he Free State, } \\
\text { South Africa }\end{array}$ \\
\hline $\begin{array}{l}{ }^{4} \text { Department } \\
\text { Administration } \\
\text { Management, } \\
\text { Economic and } \\
\text { Sciences, Univ } \\
\text { Free State, Blc } \\
\text { South Africa }\end{array}$ & $\begin{array}{l}f \text { Public } \\
\text { and } \\
\text { Faculty of } \\
\text { Management } \\
\text { ersity of the } \\
\text { emfontein, }\end{array}$ \\
\hline $\begin{array}{l}\text { Correspondin } \\
\text { Johan Coetze } \\
\text { coetzj@ufs.ac }\end{array}$ & $\begin{array}{l}\text { author: } \\
\text { za }\end{array}$ \\
\hline $\begin{array}{l}\text { Dates: } \\
\text { Received: } 17 \mathrm{~J} \\
\text { Accepted: } 30 \\
\text { Published: } 26\end{array}$ & $\begin{array}{l}\text { une } 2020 \\
\text { Jov. } 2020 \\
\text { Apr. } 2021\end{array}$ \\
\hline $\begin{array}{l}\text { How to cite th } \\
\text { Coetzee, J., Ne } \\
\text { Stemmet, K., } \\
\text { Motsitsi, C. \& } \\
2021, \text { 'South } \\
\text { universities in } \\
\text { increasing dis } \\
\text { African Journ } \\
\text { and Managen } \\
24(1), \text { a3739. } \\
\text { org/10.4102/s } \\
\text { v24i1.3739 }\end{array}$ & $\begin{array}{l}\text { is article: } \\
\text { neh, B., } \\
\text { amprecht, J., } \\
\text { Sereeco, W., } \\
\text { frican } \\
\text { a time of } \\
\text { uption', South } \\
\text { l of Economic } \\
\text { ent Sciences } \\
\text { ittps://doi. } \\
\text { ajems. }\end{array}$ \\
\hline Read online: & \\
\hline 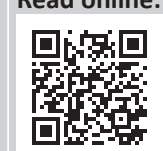 & $\begin{array}{l}\text { Scan this QR } \\
\text { code with your } \\
\text { smart phone or } \\
\text { mobile device } \\
\text { to read online. }\end{array}$ \\
\hline
\end{tabular}

Background: The Fourth Industrial Revolution (4IR) and the Coronavirus Disease 2019 (COVID-19) have disrupted the higher education environment in unprecedented ways.

Aim: This article identifies the impact of increasing disruption driven by the 4IR and COVID-19 on the content and curriculum design of degree programmes in economic and management sciences offered by South African universities.

Setting: Six South African and five top-tier US and UK universities.

Methods: The study used a non-positivist qualitative research design and specifically the casestudy approach. A document analysis of the information in university yearbooks and prospectuses was conducted, using a purposive sampling design.

Results: An online presence will become more important due to increased disruption, and will not only ensure an additional revenue stream, but also promote continuity in operations and mitigate threats from competitors. COVID-19 has accelerated the extent of this disruption and expedited the migration to online teaching and learning platforms.

Conclusion: Since science, technology, engineering and mathematics are integral to the majority of 4IR-related modules, South African universities must not shy away from degree programmes that ignore inter- and multi-disciplinary curriculum designs. Coupled with the challenges facing the majority of South African students to access electronic devices, data and the internet, COVID-19 has thrust this challenge to the forefront in the South African higher education landscape. By comparing the developments in South African universities with those in trendsetting, top-tier, global universities, management can assess the extent to which they are internationally competitive and adapting to the demands of the 4IR.

Keywords: Fourth Industrial Revolution; South Africa; massive open online courses; MOOC; university; COVID-19.

\section{Introduction}

Universities face a very real threat of becoming archaic institutions that offer irrelevant programmes to the graduate of tomorrow, if they do not adapt to the so-called Fourth Industrial Revolution (4IR). The 4IR will usher in a business environment that embeds the use of technology to disrupt and challenge conventional thinking and practices, forcing new business models that utilise different skill sets. It is therefore expected to cause major changes in society, and equipping graduates from institutions of higher learning to meet these demands will require a fundamental rethink of how curricula are designed to meet this challenge. The COVID-19 (Coronavirus Disease 2019) pandemic will accelerate these changes at a rate that was not anticipated even a few months before the spread of the virus to South Africa in early 2020. Thus, this article considers developments in curricula from selected top-tier universities vis-à-vis the 4IR, while also considering how the teaching and learning environment is set to change in a post-COVID-19 world. The findings will inform management within South African universities.

\section{Background to the problem and purpose of the study}

The pace of technological change is faster today than ever before in human history and this is reflected in the education sector. The World Economic Forum (WEF) (2016) estimates that nearly $50 \%$ of subject knowledge acquired during the first year of a four-year technical degree will be outdated by the time the student graduates. They further state (2016:3) that ' $65 \%$ of children entering primary school today will ultimately end up working in completely new job types that

Copyright: @ 2021. The Authors. Licensee: AOSIS. This work is licensed under the Creative Commons Attribution License. 
don't yet exist'. Drivers such as a more flexible working environment, mobile internet, cloud computing, big data, the internet of things (IoT), a sharing economy, robotics, artificial intelligence, and automation will revolutionise the working environment of the future (WEF 2016). The change will potentially be, as Bhalla et al. (2017) state, 'a tidal wave of change ... that will soon make the way we work almost unrecognisable to today's business leaders'. Effectively, they argue, dramatic change will become the norm: 'In an age of rapidly evolving technologies, business models, demographics, and even workplace attitudes ... change is not only constant but also exponential in its pace and scope'.

Universities must be responsive to this. In particular, the curricula they offer would need to be increasingly more dynamic and adaptable, almost, it can be argued, simultaneous to the demand for new skills dictated by the 4IR. A speedy response is, therefore, crucial in an increasingly innovative environment, but is a concern in the South African higher education environment (Rodney-Gumede 2019) where only 11 out of 26 universities have introduced modules and degree programmes responding to the skills demand of the 4IR (Pandor 2019). Moreover, given that the so-called STEM ${ }^{1}$ (science, technology, engineering and mathematics) disciplines are sure to dominate 4IR-related content, for South African universities this is particularly concerning because schools are not providing them with entrants that have the requisite STEM skills to enter programmes dealing with 4IR-related content. Considering that $78 \%$ of Grade 4 learners cannot read for meaning (Howie et al. 2016) and 79\% of Grade 6 Mathematics teachers have subject-content knowledge level lower than that of the Grade 6 learners they teach (Venkat \& Spaull 2015), the quality of mathematics and science in South African public schools rank as being of the worst in the world (WEF 2017). This is exacerbated by the fact that South African universities only accept entrants into the sciences with a pass mark of above $50 \%$ in Mathematics, whereas the number of matriculants achieving above $40 \%$ in their final examinations fell almost 11\% from 2018 to 2019 and reflected just over $41 \%$ of total bachelor passes in 2019 (DHET 2020). With only $29.1 \%$ and $28.7 \%$ of all university graduates eventually qualifying in the fields of science, engineering and technology in 2016 and 2018 (DHET 2018, 2019), there are clear indications of an education system with major structural concerns at the secondary schooling level.

The president of South Africa has realised this and appointed a task team to focus on upskilling school learners. In the 2019 State of the Nation (The Presidency 2019c) address, he announced that a number of subjects related to technology would be introduced into the school curriculum in coming years (The Presidency 2019a). So too the Department of Basic Education (DBE) has indicated that teachers would be trained in computer skills and coding, with the latter being piloted in 1000 schools in five provinces as from 2020 (Businesstech 2019).

1.References are also often made to STEAM, where Arts are also included to incorporate, in particular, the liberal arts.
The DBE further confirmed that Robotics would be offered as a subject from Grade 9 onwards. As stated by the Minister of the DBE (BusinessTech 2019):

This [the introduction of Robotics in curricula] will not only develop STEM skills, but also contribute to effectively developing children's creativity, critical-thinking, design-thinking, and digital skills [that will] ensure that South Africa develops learners who are makers and inventors who will contribute to building an innovative culture in South Africa. (n.p.)

To further support this, the president announced the merger of the departments of Higher Education and Training with Science and Innovation (The Presidency 2019b). Whether or not these proposed initiatives will achieve the desired effect, given the dire state of the quality of mathematics and science teaching at school level remains to be seen.

Besides considering the practical challenges facing the South African higher education sector, the devastating effects of the COVID-19 pandemic in 2020 have challenged universities all over the world to change the way they operate. With over $80 \%$ of the world's student population affected as a result of imposed lockdowns (Sahu 2020), especially those at universities that offer a face-to-face teaching and learning environment, the use of technology has become more pervasive than ever before. This has forced universities around the world to recognise the need to adapt to technology as the only practical approach to saving the 2020 academic year (Mohamedbhai 2020). By implication, the expedited move towards a digital-based online teaching and learning environment has transpired without prior warning, and preparation and implementation has been on a largely ad hoc basis. In Africa this unplanned sudden move to digital is a particularly large problem. Tamrat and Teferra (2020) indicate that 'only $24 \%$ of the African population has reliable access to the internet', which inadvertently raises concerns regarding the quality of the teaching and learning experience (Mohamedbhai 2020). The internet penetration rate of South Africa is substantially higher than fellow African countries at $62 \%$ and, although lower than counterparts in the developed world such as North America (88\%), Western Europe (92\%), Northern Europe (95\%) and Southern Europe (83\%), it compares favourably with emerging economic blocks such as Central America (66\%), Caribbean (60\%), Eastern Asia (63\%) and South East Asia (66\%) (Datareportal 2020). Needless to say, improving access to the internet is a priority for the South African government (The Presidency 2019b).

Although COVID-19 has identified major structural concerns for universities, there is the potential to use it to implement long-term strategies that will digitalise their online teaching and learning environment in the future (Khagram 2020), and in particular to align themselves to developments in the 4IR. Universities will therefore not only have to speedily adapt to the challenges of equipping graduates for the rigours of the 4IR, but also skilling entrants from a public schooling system with structural weaknesses (Mouton, Louw \& Strydom 2013). For the former, the ability of universities to 
incorporate new modules into curricula at a rate commensurate to the ever-evolving work environment is key to sending graduates into the workplace to meet the demands of the 4IR; for the latter, the added pressure on them to commit resources to upskill or even reskill, in particular, the STEM knowledge of incoming students from the school system. COVID-19 has at the very least provided the platform to accelerate these processes. Based on these arguments, this study focuses on the former - that is, it considers what toptier universities are incorporating into their curricula to address the rigours of the $4 \mathrm{IR}$ and the developments in the technology-driven space that directly affect the modus operandi of South African universities. More specifically, the article investigates the developments in curricula focusing specifically on economic and management sciences (or in a broader sense, commerce) for South African and a selected group of international universities, in order to assess what content they are incorporating to address developments within the 4IR. By comparing the developments in the South African situation with trendsetters (top-tier global universities), as well as technology-related developments, a judgement can be made as to what extent South African universities are adapting to a time of disruption that is unprecedented, especially with regard to the effect that COVID-19 has had on higher education globally.

The following structure is used: in the article the typical skill sets expected from graduates entering the 4IR, are first considered, and then the effect of Covid-19 on the high education sector. Following this, the content of curricula in leading universities is investigated in: (1) South Africa, (2) the developed world (top-tier universities in the United States and the United Kingdom) and (3) online offerings such as massive open online courses (MOOCs) to ascertain what content they include to equip graduates for the 4IR. In conclusion, the article identifies the major findings and makes recommendations for South African university management vis-à-vis developments in curricula in the broader field of commerce in an increasingly disrupted world.

\section{Literature review}

\section{The Fourth Industrial Revolution and developments in skills}

The 4IR is currently one of the most commonly discussed topics among academics, researchers, practitioners and policymakers across the globe. The term 'Fourth Industrial Revolution' was initially coined during the Hannover Fair in 2011 and officially announced in 2013 as part of a German high-tech strategic initiative to take a leading role in industries that were transforming the manufacturing sector (Mosconi 2015). While its origin is not doubted, its definition remains debateable (Bauer et al. 2014). In general, extant literature identifies four typical features (Hermann, Pentek \& Otto 2016; Jabbour et al. 2018; Knudsen \& Kaivo-Oja 2018; Lu 2017; Ning \& Liu 2015; Xu et al. 2018): firstly, cyber physical systems (connections between the real and virtual world), secondly, the internet of things (IoT), thirdly, the internet of services (IoS) and fourthly, the smart factory. A further study by Lorenz et al. (2015) identified nine technological pillars of the 4IR, namely systems integration, big data and analytics, simulation and virtualisation, the IoT, the cloud, cybersecurity, autonomous robots, augmented reality and additive manufacturing. The $4 \mathrm{IR}$ is therefore a broad reference to developments in technology and its integration into everyday life. More specifically, it is 'characterized by a fusion of technologies that is blurring the lines between the physical, digital, and biological spheres' (Schwab 2016).

An important consideration is the extent of the integration - it is pervasive to such an extent that it alters, and even threatens, the traditional modus operandi in the work and personal context for humans (Bawa 2017). This suggests that the skill sets required by the future worker, and thus future university graduate, will be different to those required in the past. Rodney-Gumede (2019) emphasises that the skills and experiences that were important only three years ago, will continue to shift from being industry-specific to being transformable and centred on what he refers to as the 4Cs: collaboration, communication, creativity and critical thinking. Gray (2016:1) further argues that '35\% of the skills considered important today will change as the 4IR will have brought us advanced technologies'. Skill sets will therefore not only expand, but also becoming increasingly more complex and integrated with each other, typically including complex problem solving, critical thinking, creativity, people management, coordination with others, emotional intelligence, judgement and decision-making, service orientation, negotiation, cognitive flexibility, and the management of information (Botha 2017; Rodney-Gumede 2019).

Skill sets therefore play directly into the education that future entrants into the labour force will require. Menon and Castrillion (2019) argue that university graduates must not merely receive training all-round with skills and knowledge, irrespective of the field they specialise in. Rather, due to disciplinary boundaries becoming increasingly blurred, flexibility in the curricula of qualifications would offer students 'rapid knowledge silos' and prepare them for a multifaceted and multi-disciplinary future. This, they argue, requires a holistic approach to curricula development and teaching that will empower graduates with the 'ability and agility' to adapt to the challenges of the 4IR.

The proliferation of new knowledge and the respective skills attached to it, is significant. In addition to the estimates that up to $50 \%$ of current technical curricula will be outdated by the time a student graduates, a study conducted by the WEF found that more than one-third of the respondents regarded the core skill sets of workers in 2020 to be those not considered to be important in 2016 (WEF 2016). Complex problemsolving in particular was considered to be the most important skill leading into the 4IR, followed by skills related to social, process and systems (WEF 2016). By implication, the skill set of the future requires a fusion between both traditional 'hard' skills (those associated with technical expertise) and 
'soft' skills (those associated with emotive, abstract and social dynamics). Universities therefore need to adapt modules and programmes that promise to ensure their graduates are ready and qualified for both of these (WEF 2018).

Given these escalating demands placed on universities, what would the implications be on curriculum design?

\section{Curriculum design in a changing workplace}

Suskie (2018) states that effective curriculum design focuses on the learning goals, and not necessarily only the content. This is an important consideration vis-à-vis the 4IR, as it places focus on not only the curriculum per se, but also the outcome of the curriculum and suggests an approach that is adaptive to changing societal outcomes. Two approaches typify this approach: backwards and competency-based curriculum design. For the former, the curriculum is designed with the skills and knowledge that the students should acquire by the time they graduate in mind; for the latter course credits are replaced with competencies. The importance of this is that curriculum design must shift from being the traditional discipline-based kind - in which knowledge forms the core of the curriculum - to being more constructivist or learningcentred - in which case the focus is on the development of the learner in changing times (Cullen, Harris \& Hill 2018).

Moreover, transforming the education system through curricula redesign will increasingly be measured against how educational outcomes meet the requirements of stakeholders in the workplace (Halili 2019; Panikar, Dev \& Washinton 2015). This, however, is a challenging task for educational systems (Shahroom \& Hussin 2018) that will require a re-articulation of curricula within higher education (Penprase 2018). It is further exacerbated by the fact that both the nature of work and the job market are changing and will continue to change at an increasing pace (Xing \& Marwala 2017). The way curricula disseminate information, as well as how students are expected to apply the information, suggests that even those studying in a field such as the humanities where the technical skills attached to, say, technology are not as prevalent, need to ensure that they at the very least understand the founding principles (if not the ethical principles) of new developments in technology (ButlerAdam 2018). By implication, Penprase (2018) suggests that education strategies must prioritise human skills to maximise the development and empowerment of graduates in an allrounded manner, focusing specifically on cultural, socioeconomic and interpersonal skills. In essence, curriculum development must equip graduates with the capabilities and skills that technology is not able to replace (Shahroom \& Hussin 2018) and be designed in such a way to not only teach and develop new skills, but also to also do this as the demand for skills evolves (Hussin 2018). In doing this, not only will universities train graduates to have a mindset aimed at lifelong learning, but reposition themselves to remain relevant as long as they themselves evolve amid new developments ushered in by the 4IR (Halili 2019). This evolution will be driven by an integrated approach to curricula development (Xing \& Marwala 2017) that focuses on developing the capacity of students to comprehend the impact of technological advances on humans (Bawa 2017). A more inter- and multi-disciplinary mindset will be required in which lifelong learning becomes central to developments in the job market (Hong 2017; Horowitz \& White-Burke 2018).

Although the 4IR, in and by itself, is the driving force behind the disruption facing universities, the rate at which it is set to occur has been expedited due to the COVID-19 pandemic.

\section{Disruption amid COVID-19}

The novel COVID-19 pandemic, which by all accounts started in the Chinese city of Wuhan in late 2019, has rapidly spread across many countries around the world. In response, many have introduced both local and international travel restrictions and imposed strict lockdown regulations. As of the end of March 2020, over 150 countries had closed down schools and universities affecting over $80 \%$ of the world's student population (Sahu 2020). This has created a host of unexpected challenges from both the university's and the student's perspective. Many universities have been forced to rapidly transition from traditional face-to-face teaching to different forms of online delivery modes (Gewin 2020), resulting in unplanned expenditures. Also, while online teaching is not necessarily a new mode of delivery for the majority of universities, many staff members were found wanting technologically savvy and had to acquire the skills of online learning platforms without the requisite training (THE 2020). Many academic staff members also do not have the experience of designing learning material for the online environment (Bao 2020). The added pressure of working from home, while in many instances also being required to homeschool children, has added further pressure due to not necessarily having a work environment conducive to productivity (Gorlick 2020). Assessments in the online environment have created further challenges. For example, assessments developed for a face-to-face environment had to be transformed to online assessments, which have raised concerns regarding not only their quality, but also the likelihood of encouraging cheating in the online environment (Watson \& Sottile 2010). Two recent examples include online cheating at the Georgia Institute of Technology and Boston University where students used the help of the education technology company Chegg to complete online assessments (Flaherty 2020). The aforesaid has thus disrupted universities in ways unimaginable before the onset of COVID-19.

Moreover, the majority of students in South Africa are reliant on the computer labs, Wi-Fi connections and libraries available on the campuses of universities. Due to many not having access to any of these at home, COVID-19 has forced them to rely on data plans provided by universities and their smartphones to attend and complete online classes and assessments (Mathiba 2020). Students who, therefore, lack access to digital devices are at a clear disadvantage, which has implications on both the grades they receive and the 
likelihood to defer their studies (Alruwais, Wills \& Wald 2018). Furthermore, students used to the face-to-face environment require a heightened sense of self-discipline and a learning attitude conducive to online learning (Bao 2020). The speed at which students have been forced to adapt, places them under immense pressure and raises concerns regarding the value for money they get while paying for tuition that presupposes the full ambit of a traditional faceto-face teaching and learning environment (Burki 2020). With most accounts suggesting that a vaccine is expected in 2021, the reality is that universities and students will have to endure the online environment into late 2021 and, most likely, later (Le et al. 2020).

\section{Research methods}

This study adopts a non-positivist qualitative research design and specifically the case-study approach, which aims to 'build a holistic, largely narrative, description to inform the researcher's understanding of a social or cultural phenomenon ... [emerging] organically from the research context' (Astalin 2013:118). Although qualitative research, and by implication a case study, adopts an 'interpretative paradigm' that may be construed as being subjective from the perspective of the researcher (Starman 2013:30), the suggested bias has been argued to be misguided as case studies, in particular, explore real-world situations 'as they unfold in practice' (Flyvbjerg 2011:309). To ensure this, and specifically scientific rigour, the results need to be unbiased, trustworthy, credible and confirmable (Guba \& Lincoln 1982; Morse, Olson \& Spiers 2002). As such, a documentary analysis was conducted from those available in the public domain on the websites of the chosen universities - more specifically, a 'documents as commentary approach' according to which 'insight into individual and collective ... practices and structures that are not otherwise observable' was adopted (Atchan, Davis \& Foureur 2017:56). Yearbooks or prospectuses from the faculties of economic, management and business sciences (or broadly speaking, commerce) were identified after which critical probing into the content (Atchan et al. 2017) allowed the content, and specifically modules within curricula, to be identified through the 'orientation of qualitative description' (Oczkowskia et al. 2018:59). The study, therefore, follows an inductive approach, typical of qualitative research designs and allows 'research findings to emerge from the frequent, dominant, or significant themes inherent in raw data, without the restraints imposed by structured methodologies' (Thomas 2006:238).

The study used a non-probability sampling design and more specifically purposive sampling. The sampling frame comprised South African and top-tier United States and United Kingdom universities. The overarching criterion used for selection was the availability of information regarding the modules in curricula focusing on degrees in commerce. Based on this, six South African universities were selected and five of the top six global universities according to the QS University Rankings. Table 1 provides the list of these universities.
TABLE 1: Selected universities used for the study.

\begin{tabular}{lccl}
\hline Variable & Global ranking & Country ranking & Location \\
\hline South African university & 121 & 1 & South Africa \\
University of Cape Town & 200 & 2 & $\begin{array}{l}\text { South Africa } \\
\text { University of the Witwatersrand }\end{array}$ \\
$\begin{array}{l}\text { Stellenbosch University } \\
\text { University of Johannesburg }\end{array}$ & 329 & 3 & South Africa \\
$\begin{array}{l}\text { University of Pretoria } \\
\text { University of the Free State }\end{array}$ & 441 & 5 & South Africa \\
Top-tier university & 970 & 11 & South Africa \\
$\begin{array}{l}\text { Massachusetts Institute of } \\
\text { Technology }\end{array}$ & 1 & & South Africa \\
Stanford & 2 & 1 & United States \\
Harvard & 3 & 2 & United States \\
Oxford & 5 & 3 & $\begin{array}{l}\text { United States } \\
\text { United }\end{array}$ \\
Cambridge & 6 & 1 & Kingdom \\
\hline
\end{tabular}

Source: Global Universities Rankings, 2019, US news best global universities rankings, viewed 12 August 2019, from https://www.usnews.com/education/best-global-universities/ rankings; and QS, 2019, World university rankings, viewed 25 May 2019, from https://www. topuniversities.com/university-rankings/world-university-rankings/2019.

At the risk of merely providing a summary of the modules in university curricula, we need to explain what is meant by '4IR-related content'. For purposes of the study, this refers specifically to modules that deal with topics within the curricula of qualifications in the field of commerce that, in the broadest sense, are expected to deal with those relating to the 4IR. Generally speaking, this includes, but is not necessarily limited to, data science, business analytics and fintech in a specifically commerce-related degree programme. More specifically this includes modules focusing on technology, the management, analysis and dissemination of information and data - including coding, programming and the like, simulation, digitalisation, machine learning, robotics, big data, blockchain, IoT, artificial intelligence and so on. A caveat on this is in order: although the yearbooks (or prospectuses) providing information on the respective modules are informative as to the name of the respective modules, and they usually provide a list of the expected outcomes, detail of the content is typically sparse. For this reason, the study does not specifically consider the content within modules themselves, but rather identifies modules that, through their names, describe content linked to topics associated with the 4IR.

\section{Ethical considerations}

This article followed all ethical standards for research without direct contact with human or animal subjects.

\section{Findings South African universities}

South African universities offer traditional commerce degrees, but have introduced 4IR-related modules as either electives or as part of the core modules. For example, at the University of Cape Town (UCT) students studying towards a BCom can specialise in 'traditional' areas including accounting, actuarial sciences, economics and management, whereas students studying towards a BBusSc can specialise in 12 areas 
(UCT 2018a), including analytics and information systems, dealing specifically with analytical methods pertinent to advances in the 4IR or modules more interdisciplinary by nature, such as cognitive neuroscience. At Stellenbosch University (SU) a BCom is offered in mathematical statistics with a focus on data science, focusing specifically on requiring students to gather, store, transform and graphically represent data (US 2019). In the field of business management at the University of Pretoria (UP), there have been substantial changes with the introduction of modules, such as design thinking and business innovation, business analytics (including topics such as data mining, big data and data stream analysis), and responsible leadership (UP 2019).

Universities also acknowledge the roles of both inter- and multi-disciplinary degrees with a 4IR flavour. At both UCT and the University of the Witwatersrand (Wits) (2019), degrees specialising in philosophy, politics and economics (PPE) follow the practice of prestigious top-tier universities such as the London School of Economics and Political Science, ${ }^{2}$ the University of Pennsylvania ${ }^{3}$ and the University of Oxford. ${ }^{4}$ With a slight tweak, the University of Johannesburg (UJ) introduced a Bachelor of Arts (BA) degree in 2019 specialising in politics, economics and technology with the specific purpose of equipping students for the 4IR, relying heavily on the expertise from different faculties, including the College of Business and Economics (CBE) and the Faculties of Humanity and Science (UJ 2019). The University of the Free State (UFS) in 2020 introduced a BCom specialising in business and financial analytics focusing specifically on addressing the potential 4IR skills of the future graduate, with modules focusing on integrating traditional banking and finance topics with those typical of data analytics, such as programming and problem solving, databases and database management systems, and data analytics for business (UFS 2020).

In general, South African universities understand the important role of data and information management in their commerce degrees. Wits offers a BCom Information Systems, UCT and SU offer modules focusing on information systems as core in the first year of study and UP a BCom Informatics Information Systems, dealing with the management of information systems, manipulation of data and computer programming. At UJ, the School of Consumer Intelligence and Information Systems integrates IT and computer sciences in the field of commerce to enable students to develop software, manage information systems and program.

In addition to traditional departments within commerce faculties, certain business schools also offer a host of modules on topics pertinent to the 4IR. For example, at Wits the Graduate School of Business Administration offers a Master of Management in the field of digital business,

\footnotetext{
2.See http://www.lse.ac.uk/study-at-Ise/Undergraduate/Degree-programmes-2020/ BSc-Philosophy-Politics-and-Economics.
}

3.See https://ppe.sas.upenn.edu/.

4.See http://www.ox.ac.uk/admissions/undergraduate/courses-listing/philosophy politics-and-economics. which includes modules such as Systems Thinking in the Digital Economy, Applied Big Data and Analytics, Cybersecurity and Risk Management, Digital Financial Services, Digital Government, Digital Commerce, Business Strategy for a Digital World, Marketing for Digital Business, Digitalising Operations, Innovation and Entrepreneurship in Digital Business, Digital Transformation and Change Management and Digital Technology (Wits 2019). The Gordon Institute of Business Science (GIBS) of the UP offers a Senior Executive Programme with the Harvard Business School with 4IR modules such as Competing in the Age of Digital Platforms, Competing on Business Analytics and Big Data, Driving Digital Strategy and Leading an Agile Workforce Transformation. ${ }^{5}$ The provision of 4IR content is therefore not limited to traditional departments within the faculties of commerce, but extends to the offerings of business schools in certain instances.

Ensuring that graduates are well versed in the principles of ethical behaviour in the workplace is required by several professional qualifications, typically offered by different departments within the faculties of commerce. For example, when graduates qualify as Chartered Accountants in South Africa, they have to adhere to the ethical requirements prescribed by the South African Institute of Chartered Accountants; ${ }^{6}$ when graduates in finance pursue qualifications such as the Chartered Banker, ${ }^{7}$ Chartered Financial Analyst or Financial Risk Manager, they have to adhere to the ethical requirements of the Chartered Banker Institute, Chartered Financial Analyst Institute ${ }^{8}$ and the Global Association of Risk Professionals; ${ }^{9}$ when industrial psychologists qualify as such, they have to adhere to the professional conduct and ethical standards of the Health Professions Council of South Africa. ${ }^{10}$ Although all of the universities under investigation are either affiliated or accredited by some of these bodies, particularly in their postgraduate degree programmes, the inclusion of courses focusing on ethics is not necessarily a requirement for undergraduate study.

\section{Top-tier universities in the United States and the United Kingdom}

The composition of the bachelor's degrees offered by the toptier universities in the United States and the United Kingdom are unique. For instance, the US curricula are more flexible, orientated towards being inter-disciplinary, and emphasise a broad approach to subject content. Harvard and Stanford curricula, for example, maintain a major-minor system which allows students the opportunity to select subjects outside of their major areas of specialisation. In contrast, Oxford and Cambridge offer curricula that are more rigid and orientated

5.See https://www.gibs.co.za/programmes/open-programmes/pages/harvard-businessschool-senior-executive-program.aspx.

6.See https://www.saica.co.za/.

7.See https://www.charteredbanker.com/.

8.See https://www.cfainstitute.org/.

9.See https://www.garp.org/.

10.https://www.hpcsa.co.za/ 
towards in-depth specialisation (also called majors, concentrations or triposes) in various fields.

An interesting dimension of the curricula of Harvard, Stanford and the Massachusetts Institute of Technology (MIT) is the so-called general educational requirement (or general institutional requirement at MIT) that needs to be completed by all students irrespective of their area of specialisation. The aim of this requirement is to develop a set of essential intellectual competencies and social skills to broaden the exposure of students to a plethora of different disciplines - it is therefore multi-disciplinary at its core. For example, the content is not only spread among courses in the traditional sciences, humanities, arts, social sciences, and technology, but also covers exposure to soft skills associated with improving writing and speaking, planning, reasoning, culture, diversity, foreign languages and cultures, ethics, and belief systems to name only a few (Harvard University 2019a; MIT 2019b; Stanford University 2019c). At MIT there is even a 'physical education requirement' which entails a minimum of four physical education courses and the requirement to pass a 100-yard swimming test - the rationale being that both the body and mind need to be healthy and are not independent of one another (MIT 2019b).

The top-tier universities offer students substantial choices in the composition of their curricula. For example, although MIT awards only one undergraduate BSc degree, a major (or specialisation) is selected out of a possible 54 fields (MIT 2019a). In turn, Stanford University offers students BA, a BSc or a BA\&Sc with a major from a possible 65 fields, constituting at least one-third (but not more than two-thirds) of a student's programme (Stanford University 2019a). Harvard offers more than 3700 courses in 50 undergraduate fields of studies, albeit not offering a business concentration to undergraduate students (Harvard University 2019b). Furthermore, at the University of Cambridge an undergraduate BA (Hons) degree with more than 65 subjects is offered (Cambridge University 2019). Therefore, although top-tier universities offer students considerable flexibility, balance is sought between the depth of knowledge acquired when specialising in a specific major and the breadth of knowledge acquired through broader exploration of multiple disciplines (Stanford University 2019b).

Specialist undergraduate programmes that speak directly to the principles of 4IR content are further reflected in interdisciplinary curricula. With a BSc in Computer Science, Economics and Data Science at MIT, subjects include, among others, Fundamentals of Programming, Introduction to Algorithms, Design and Analysis of Algorithms, Econometric Data Science, Communicating with Data, Networks and Optimization Methods in Business Analytics, Networks, Economics and E-commerce, and Data Analysis for the Social Scientist (MIT 2019d). Moreover, the Department of Economics at Stanford offers students courses in social and economic networks and the future of finance, which directly address the pressing issues in the current landscape of global financial markets such fintech, regtech, artificial intelligence, crowd financing, blockchain, machine learning and robotics, IoT, cybersecurity, financial warfare, cryptocurrency risks, ETFs, new instruments and payment platforms, roboadvising, and big data and algorithmic trading (Stanford University 2019d). Students majoring in economics are offered electives from outside departments, including Mathematics, Statistics, Computer Science and Overseas Studies. Electives include, among others, Design and Analysis of Algorithms, Artificial Intelligence: Principles and Techniques, Machine Learning and General Game Playing (Stanford University 2019e).

Furthermore, postgraduate studies are typically offered by the business schools of the respective universities. At MIT, modules that have a distinct 4IR flavour include: Information, Entropy and Computation Econometrics for Managers: Correlation and Causality in the Big Data World, Statistical Thinking and Data Analysis, Introduction to Machine Learning, Introduction to Applied Probability, Data Mining: Models and Predication that Create Value, The Analytics Edge, Artificial Intelligence, Predictive Data Analytics and Statistical Modelling, Negotiation Analysis and Algorithmic Trading and Quantitative Investment Strategies (MIT 2019c). Stanford requires MBA students to complete compulsory core modules in the MBA, such as Ethics in Management, Optimization and Simulation Modelling, Data Analysis and Decision Making, and Information Management, with over 100 modules in the second year of the MBA programme, including but not limited to Cryptocurrencies, The Evolution of Finance, Digital Marketing, and Data Science for Platforms (Stanford University 2019f). At Harvard, commerce subjects are presented by both the Faculty of Arts and Sciences and the Harvard Business School. The MBA offers a specialised module called Tech Ethics: AI, Biotech, and the Future of Human Nature, which explores the moral, social and political implications of new technologies (Harvard University 2019b). Harvard Business School also offers the courses Economics of Networks and Using Big Data to Solve Economic and Social Problems (Harvard University 2019b). The MBA at the Saiid Business School at Oxford University further offers specialised modules such as Digital and Social Media Strategy, Fintech: Present and Future, and the Digital Transformation of Marketing, Media, and Advertising (Oxford University 2019a, 2019b).

\section{Massive open online courses, short courses and MicroMasters ${ }^{\circ}$}

In recent years universities have aggressively pursued the use of technology in the provision of specialised and shorter online-based programmes. Top-tier universities in particular have focused on offering MOOCs which provide free courses through partners such as edX, Coursera and Udemy. edX, for example, was formed in 2012 when Harvard joined MIT to allow an open-source online learning platform to distribute course content and other academic material of over 2400 courses, collaborating with top-tier universities across the world. ${ }^{11}$ As an extension of edX, mooc.org provides a database 11.See www.edx.org. 
on all the available MOOCs with a substantial number of courses focusing on 4IR-related content such as artificial intelligence, big data, blockchain, computer science, cybersecurity, data science, machine learning, Python, R programming, and robotics. ${ }^{12}$

For a nominal fee, top-tier universities offer online short courses focusing on industry-relevant content, and especially those related to the 4IR. Usually marketed as online certificate courses in either 'Executive' or 'Professional Education', these courses are typically presented in collaboration with an IT collaborator such as Emeritus, Getsmarter or Greater Learning which facilitate the entire online process, running for periods averaging 6-12 weeks. In South Africa, universities such as UCT and SU offer similar featured online certificates on topics such as data science and fintech. ${ }^{13}$

A further development in recent years has been the so-called MicroMaster ${ }^{\circledR}$ programmes, the logic of which is to enable prospective students the opportunity to do smaller, more manageable, postgraduate courses in topics that will ultimately count for recognition (credit) in full master's degrees at the respective university. Offered by top-tier universities, they are more expensive than short online certificate courses, but cheaper than full master's programmes, and typically run for periods of 6 months to usually not longer than 1 year. ${ }^{14}$ Programmes related to the 4IR are particularly prevalent, with examples including MicroMaster ${ }^{\circledR}$ certificates in 'Statistics and Data Science' from MIT, 'Marketing Analytics' from the University of California at Berkeley, 'Integrated Digital Media' from New York University, 'Data Science' from the University of California at San Diego, 'Artificial Intelligence' by Columbia University, and 'Marketing in a Digital World' offered by Curtin University to name only a few.

\section{Discussion and implications Discussion of the findings}

The 4IR requires a different way of thinking and will blur the boundaries between content on its own and the application of the content where integration in an inter- and multidisciplinary setting will increasingly become the norm. South African universities incorporating subjects such as economics, politics, technology and philosophy, similar to that of top-tier international universities, are examples of this and reflect the more integrated approach to curricula attempting to upskill graduates entering the 4IR. This is particularly important amid concerns about skills constraints inhibiting economic growth in South Africa (Burger 2018).

\footnotetext{
12.See www.mooc.org.

13.See https://www.getsmarter.com/universities/university-of-cape-town?\&ef_id= c:326879540764_d:c_n:g_ti:kwd-364334305164_p:_k:uct\%20online $\% 20$ courses_m:e_a:60368263834\&gclid=EATaIQobChMIrLCGnp I4wIVFPIRCh18GgK4EAAYASAAEgJ-3_D_BwE; https://masterstart.com/courses? utm source=google\&utm_medium $=$ cpc\&utm_campaign=allcourses $\&$ keyword $=$ on $\% 20$ line $\% 20$ courses $\&$ matchtype $=$ p\&device $=$ c\&gclid=EAlalQobChMIr LCGnp_I4wIVFPIRCh18GgK4EAAYAiAAEgIk2_D_BwE
}

14.See https://www.edx.org/micromasters.
The South African universities investigated in this study acknowledge that 4IR-related content is important in commerce degrees. In most part there does not seem to be a mass overhaul of curricula, but rather that core modules tend to remain largely the same and are supplemented by additional modules addressing topics related to the 4IR. Furthermore, business schools seem to play an important role in the presentation of modules related to the 4IR. This is probably due to their role to stay current and adaptable to market trends, although the criticism is that content is not always as dynamic as it should be (Denning 2018). Needless to say, 'authentic engagement' between the relevant stakeholders to ensure meaningful curriculum changes, requires 'ongoing conversations' as the process becomes increasingly more dynamic amid the 4IR (UCT 2018b). In turn, top-tier universities offer degrees that are fundamentally multi-disciplinary and offer a wide and extensive range of modules in undergraduate programmes. Students are therefore encouraged to select from various disciplines. At postgraduate level, business schools, as opposed to discipline-specific departments, offer coursework and the range of specialised modules focusing on 4IR is extensive.

COVID-19 has set the scene to rapidly change the teaching and learning environment for South African universities. For universities to remain sustainable post-Covid-19, they have to change their business models as the traditional face-to-face mode of teaching and learning will no longer be the only feasible approach. Blended online learning approaches such as HyFlex may be considered in which students are given the option to attend classes either in person or in an online setting. By implication, besides adapting curricula to developments in the 4IR, universities need to start thinking differently about how they train students by strengthening their active learning abilities outside of the traditional face-to-face context.

\section{Managerial implications}

Six managerial implications for the management of South African universities are posited.

\section{An online presence will become increasingly important for revenue and continuity reasons}

Although face-to-face learning is the main mode of teaching at the majority of South African universities, having an online presence is becoming increasingly important, especially amid the COVID-19 pandemic. There are main drivers for the move towards a more integrated online presence in the teaching and learning environment for universities: firstly, South African universities need to become more competitive, compared to international universities, by focusing on South Africa-specific content; secondly, assuming the labour and physical resources are available, an online presence ensures an additional revenue stream in a higher education environment where the state is shifting the financial burden increasingly to students to fund their tuition (Czerniewicz, Trotter \& Haupt 2019); thirdly, and arguably most importantly, an online presence will contribute to ensuring continuity in teaching and learning due to an increasingly disrupted 
higher education environment. The latter two reasons in particular support moving content to the virtual space as it provides some sort of continuity in the delivery of classes during times of strikes, protests and disruptions on campus such as those seen during the \#FeesMustFall movement in 2015 and 2016, the unpaid National Student Financial Aid Scheme allowances in 2020, and the COVID-19 pandemic, which will continue into at least 2021 (Mafolo et al. 2020; Mbolekwa 2020; Geduld \& Sathorar 2016). Given the highly politicised higher education environment in South Africa, adopting a hybrid (or blended) approach to class delivery may become the status quo in the future, despite the challenge of not all students having access to electronic devices or the internet due to coming from poor and working-class households (Brodie \& Harding 2020).

\section{The integration of science, technology, engineering and mathematics skills is integral to curriculum design}

The 4IR will revolutionise the way society operates and STEM subjects will be the foundation of this. The focus on equipping future graduates with the requisite skills to meet the demands of the 4IR, must, however, not overshadow the realities facing the quality of education received by the majority of students prior to entering South African universities. The poor performance of the vast majority of South African school-leavers in STEM subjects is a concern for universities, reiterating the structural challenges in specifically the spheres of mathematics and science education.

This is also exacerbated by the fact that the so-called Millennials and Generation $\mathrm{Z}$ require a different mindset as to how knowledge is disseminated. The use of technology in the classroom is central to this and shorter attention spans and the pervasive use of technology require educators to present classes in far more interesting and stimulating ways than in the past (Giunta 2017). Although one study suggests that the attention span for Generation Z's is $8 \mathrm{~s}$ (Elmore 2014), universities must adapt curricula, taking into account the changing behavioural and technological habits of students as well, yet at the same time being sensitive to the challenges many South African students have regarding access to digital devices. COVID-19 and any such disruptive event in the future, has arguably made this more relevant than ever before.

\section{A mass overhaul of curricula is not required}

Although a few specialised degrees have been established, the general trend seems to be that universities are supplementing existing degree curricula with additional modules pertinent to the 4IR. With the exception of specialised degrees, especially at top-tier universities, degrees seem to be quite 'fluid', as the focus is rather to complement core modules, related to the traditional area of specialisation, with those expected from the 4IR. This feature is considered favourable for South African universities as it 'facilitate[s] the creation of new work fields at the intersection of knowledge domains' (Bawa 2017). Universities should therefore not necessarily be lulled into a mindset that they need to 'provide everything to everyone' through a mass overhaul of curricula, but maybe consider building in more flexibility in module selection within degree programmes. Top-tier universities in particular have adopted a very explicit inter- and multidisciplinary approach to their curricula, with several South African universities having recently followed suit.

\section{Due to the pervasiveness of online content, the reputation of universities to provide formal and reputable qualifications will be pivotal to their success}

Already MOOCs and platforms such as YouTube threaten the dissemination of information offered by institutions of higher learning, especially those not offering the former. By implication, if information is so pervasive and cheaper alternatives to disseminate it in the public domain potentially threaten the existence of universities, what would motivate a student to pay for a formal education at a university rather than through (1) cheaper online-based programmes from reputable top-tier universities or (2) free online content such as MOOCs? The threat this poses to universities with a dominantly face-to-face teaching and learning environment, is exacerbated as their tuition fees are higher than universities that offer an exclusively online environment. The forced sudden reaction of universities to COVID-19 has exposed this reality and threatens to result in students switching to universities which have the technological infrastructure to deal with online teaching and learning. Needless to say, the answer to the question arguably lies in the reputational benefits of qualifying from a university of repute. For a South African university, this suggests competing with the best universities in the world, and it poses a potential threat to the competitiveness of South African qualifications if these universities are able to scale their online content and offer competitive teaching to potential South African students. As the migration to a digital teaching and learning environment due to COVID-19 has shown, the challenge will be to ensure that South African students have the necessary technology and data at their disposal to facilitate online education.

\section{Universities must require all students to take a course in ethics, specifically focusing on topics relevant to the Fourth Industrial Revolution}

Top-tier universities in particular have modules focusing on the ethical dimensions of the 4IR, given that it presupposes the integration of technology in everyday human life (Schwab 2016). Although technology has resulted in huge progress made in both the medical and business environment, concerns related to, for example, cybersecurity and the confidentiality of data raise ethical concerns with regard to privacy and the intrusive nature of data management. The question therefore becomes: can a university afford to send graduates into the workplace with no exposure to what ethics are, or how to handle unethical situations and, if so, what sort of message does it send out to the business community? Although South African business schools in particular grapple with these questions (Businesstech 2017), it is not as pervasive in curricula in general. And, as indicated above, although several professional qualifications require graduates to adhere to conduct and ethical-related standards as part of either curricula of professional affiliation in the fields of 
commerce, there is no reason why offering a compulsory module on ethics should not be applicable to every graduate in commerce, not to mention any student studying at a university who does not specialise in one of the abovementioned career paths. Clearly, therefore, there is an acknowledgment by industry that ethics and the associated conduct in unethical situations in the workplace cannot be separated from what students need to learn at university.

\section{Curricula must differentiate the skills of graduates to keep them competitive in the workplace}

Universities need to ensure that they are driven by two overarching principles leading into the 4IR: (1) students must be provided with the requisite knowledge and skills to be part of the 4IR, and (2) the knowledge students acquire must differentiate them from the 'robots' (read: artificial intelligence, machine learning, mechanisation, automation, etc.) by focusing on their abilities to problem-solve, think critically, behave with empathy, be creative, question and dream (Marr 2018). By implication, graduates must not leave university having merely acquired the skills that technology will be able to do in the future, anyway. Given the rapid rate of change that technology brings to the fore, graduates will also need to adopt a mindset that encapsulates a lifelong learning approach. The COVID-19 pandemic has no doubt reinforced this and as long as a disrupted environment is the norm of the day, lifelong learning will be part and parcel of the mindset that the graduate of the future is expected to engender. University studies will thus be a means to an end: on-the-job experience, coupled with the skills and knowledge acquired at university, will count for more in terms of being competitive in the workplace.

Finally, although the impact on students is without question, university staff also need to be mentioned, especially while COVID-19 prevents them from attending the physical workplace. Universities must implement human resource policies that are increasingly more flexible and integrated with a performance-based culture that considers homebound work pressures. With COVID-19 likely to be part of the landscape until at least 2021, any developments in curriculum design are ultimately articulated and implemented by academic staff. Without the necessary institutional support to facilitate this, the ability of university, to capitalise on developments in the $4 \mathrm{IR}$ will be a futile exercise.

\section{Conclusion}

As the custodians of disseminating knowledge, universities need to be at the forefront of equipping societies for the developments leading into the 4IR. This challenge has undoubtedly been escalated to unprecedented levels due to the COVID-19 pandemic and accelerated the rate of adoption. Given the socio-economic imbalances inherent to the South African economy, failure to do this will have severe implications on the well-being of the people and exacerbate the problem from being one of being unemployed to one of becoming unemployable. If South African universities do not adapt and do so quickly, they run the risk of losing relevance in the broader higher education environment due to the competition from especially international universities which have a strong presence in the online environment. The solution is integrating the skills of the 4IR to address South Africa-specific problems and consequently not compete directly with top-tier international universities. Rather, they must become more relevant to South African problems using the tools and skills inherent to the 4IR. This will differentiate the offerings of South African universities from those of universities in the rest of the world. As such, COVID-19 has in many ways provided the platform for universities to 'reset' their business model and use technology as the fundamental tool to provide education in a time of disruption, arguably never seen before in higher education across the globe.

\section{Acknowledgements}

This manuscript was the result of work conducted by a task team focusing on developments in curricula due to the 4IR appointed by the Faculty of Economic and Management Sciences at the University of the Free State.

\section{Competing interests}

The authors declare that they have no financial or personal relationships that may have inappropriately influenced them in writing this research article.

\section{Authors' contributions}

J.C. was the lead researcher for the design and writing up of the final manuscript. B.N., K.S, J.L., C.M. and W.S. contributed to certain sections of the manuscript.

\section{Funding information}

This research received no specific grant from any funding agency in the public, commercial or not-for-profit sectors.

\section{Data availability}

Data sharing is not applicable to this article as no new data were created or analysed in this study.

\section{Disclaimer}

The views and opinions expressed in this article are those of the authors and do not necessarily reflect the official policy or position of any affiliated agency of the authors.

\section{References}

Alruwais, N., Wills, G. \& Wald, M., 2018, 'Advantages and challenges of using eAssessment', International Journal of Information and Education Technology 8(1), 34-37. https://doi.org/10.18178/ijiet.2018.8.1.1008

Atchan, M., Davis, D. \& Foureur, M., 2017, 'An historical document analysis of the introduction of the Baby Friendly Hospital Initiative into the Australian setting', Women and Birth 30(1), 51-62. https://doi.org/10.1016/j. wombi.2016.07.004

Astalin, P.K., 2013, 'Qualitative research designs: A conceptual framework', International Journal of Social Science \& Interdisciplinary Research 2(1), 118-124. 
Bao, W., 2020, 'COVID-19 and online teaching in higher education: A case study of Peking University', Human Behaviour \& Emerging Technologies 2(2), 113-115. https://doi.org/10.1002/hbe2.191

Bauer, W., Schlund, S., Marrenbach, D. \& Ganschar, O., 2014, Industrie 4.0-Volkswirtschaftliches Potenzial für Deutschland, Fraunhofer Institut, Stuttgart.

Bawa, A., 2017, 'Time for a change at universities', Mail \& Guardian, 07 April, viewed 07 January 2020, from https://mg.co.za/article/2017-04-07-00-time-for-achange-at-universities/.

Bhalla, V., Dyrcks, S. \& Strack, R., 2017, 'Twelve forces that will radically change how organizations work', The New Way of Working Series, March 27, Boston consulting Group, viewed 15 July 2019, from https://www.bcg.com/ publications/2017/people-organization-strategy-twelve-forces-radicallychange-organizations-work.aspx.

Botha, D., 2017, 'The Fourth Industrial Revolution and knowledge management: Early stage conceptualisation', South African Knowledge Management Summit, Johannesburg, 29-31 August.

Brodie, M. \& Harding, M., 2020, 'Drastic measures in our universities need not silence students' concerns', Daily Maverick, 18 March, viewed 06 April 2020, from https://www.dailymaverick.co.za/article/2020-03-18-drastic-measures-in-ouruniversities-need-not-silence-students-concerns/.

Burki, T.K., 2020, 'COVID-19: Consequences for higher education', Lancet Oncology 21(6), 758. https://doi.org/10.1016/S1470-2045(20)30287-4

Burger, P., 2018, Getting it right: A new economy for South Africa, Sandton, KMM Publishing.

BusinessTech, 2017, Universities and business schools are changing their curricula to deal with SA's 'ethics' problem, viewed 20 June 2019, from https://businesstech. co.za/news/business/214591/universities-and-business-schools-are-changingtheir-curricula-to-deal-with-sas-ethics-problem/.

BusinessTech, 2019, 2 big changes coming to South African schools, viewed 20 June 2019, from https://businesstech.co.za/news/government/324621/2-big-changescoming-to-south-african-schools/.

Butler-Adam, J., 2018, 'The Fourth Industrial Revolution and education', South African Journal of Science 114(5/6), 1. https://doi.org/10.17159/sajs.2018/a0271

Cambridge University, 2019, Cambridge undergraduate prospective 2020, pp. 60-61 116, viewed 29 May 2019, from https://www.undergraduate.study.cam.ac.uk/ files/publications/uoc_prospectus_2020.pdf.

Czerniewicz, L., Trotter, H. \& Haupt, G., 2019, 'Online teaching in response to studen protests and campus shutdowns: Academics' perspectives', Journal of Educational Technology in Higher Education 16(43), 1-22. https://doi.org/10.1186/s41239019-0170-1

Cullen, R., Harris, M. \& Hill, R.H., 2012, The learner-centered curriculum: Design and implementation, John Wiley \& Sons, San Francisco, CA.

Datareportal, 2020, Digital 2020: South Africa, viewed 23 November 2020, from https://datareportal.com/reports/digital-2020-south-africa.

Denning, S., 2018, 'Why today's business schools teach yesterday's expertise', Forbes, 27 May, viewed 30 May 2019, from https://www.forbes.com/sites/ stevedenning/2018/05/27/why-todays-business-schools-teach-yesterdaysexpertise/\#7b13e661488b.

Department of Higher Education and Training (DHET), 2018, Statistics on post-school education and training in South Africa: 2018, viewed 07 January 2020, from http://www.dhet.gov.za/Research\%20Coordination \%20Monitoring $\% 20$ and $\% 20$ Evaluation/6_DHET\%20Stats\%20Report_04\%20April\%202018.pdf.

Department of Higher Education and Training (DHET), 2019, Post-school education and training monitor: Macro-Indicator trends, viewed 07 January 2020, from and training monitor: Macro-Indicator trends, viewed 07 January 2020, from
http://www.dhet.gov.za/SiteAssets/Post-School\%20Education $\% 20$ and $\% 20$ http://www.dhet.gov.za/SiteAssets/Post-School\%20
Training\%20Monitor\%20Report_March\%202019.pdf.

Department of Higher Education and Training (DHET), 2020, Statement on post-school education and training sector state of readiness for the academic year 2020, education and training sector state of readiness for the academic year 2020,
viewed 18 February 2020, from http://www.dhet.gov.za/SiteAssets/Media\%20 viewed 18 February 2020, from http://www.dhet.gov.za/SiteAs

Elmore, T., 2014, 'Contrasting generation $Y$ and Z', HuffPost: Parents, 15 October viewed 19 July 2019, from http://www.huffingtonpost.com/tim-elmore/ viewed 19 July 2019, from http://w
contrasting-generation-y-_b_5679434.html.

Flaherty, C., 2020, Big proctor: Is the fight against cheating during remote instruction worth enlisting third-party student surveillance platforms?, viewed 06 June 2020, from https://www.insidehighered.com/news/2020/05/11/online-proctoringsurging-during-covid-19.

Flyvbjerg, B., 2011, 'Case study', in N.K. Denzin \& Y.S. Lincoln (eds.), The Sage handbook of qualitative research, pp. 301-316, Sage, Los Angeles, CA.

Geduld, D. \& Sathorar, H., 2016, 'Leading curriculum change: Reflections on how Abakhwezeli stoked the fire', South African Journal of Education 36(4), 1-13. https://doi.org/10.15700/saje.v36n4a1319

Gewin, V., 2020, 'Five tips for moving teaching online as COVID-19 takes hold', Nature 580, 295-296. https://doi.org/10.1038/d41586-020-00896-7

Giunta, C., 2017, 'An emerging awareness of generation Z students for higher education professors', Archives of Business Research 5(4), 90-104. https://doi. org/10.14738/abr.54.2962

Global Universities Rankings, 2019, US news best global universities rankings, viewed 12 August 2019, from https://www.usnews.com/education/best-globaluniversities/rankings.

Gorlick, A., 2020, 'The productivity pitfalls of working from home in the age of COVID-19', Stanford News, viewed 06 June 2020, from https://news.stanford. edu/2020/03/30/productivity-pitfalls-working-home-age-covid-19/.
Gray, A., 2016, 'The 10 skills you need to thrive in the Fourth Industrial Revolution' World Economic Forum, viewed 21 May 2019, from https://www.weforum.org/ agenda/2016/01/the-10-skills-you-need-to-thrive-in-the-fourth-industrialrevolution/.

Guba, E.G. \& Lincoln, Y.S., 1982, 'Epistemological and methodological bases of naturalistic inquiry', Educational Communication and Technology Journal 30(4), 233-252.

Halili, S.H., 2019, 'Technological advancements in education 4.0', The Online Journal of Distance Education and e-Learning 7(1), 63-74.

Harvard University, 2019a, General education requirement, viewed 25 May 2019, from https://generaleducation.fas.harvard.edu/current_requirements.

Harvard University, 2019b, Academic programs, viewed 25 May 2019, from https:// www.hbs.edu/about/academic-programs/Pages/default.aspx.

Hermann, M., Pentek, T. \& Otto, B., 2016, 'Design principles for industry 4.0 scenarios', Proceedings of 2016 49th Hawaii International Conference on systems science, January 5-8, Maui, Hawaii.

Hong, O., 2017, STEAM education in Korea: Current policies and future directions, Policy Trajectories and Initiatives in STEM Education.

Horowitz, M. \& White-Burke, W., 2018, 'Academia can be an important vanguard of the Fourth Industrial Revolution', World Economic Forum, viewed 17 July 2019, from https://www.weforum.org/agenda/2018/01/academia-vanguard-fourthindustrial-revolution-4ir-universities/.

Howie, S., Combrinck, C., Tshele, M., Roux, K., McLeod Palane, N. \& Mokoena, G. 2016, Progress in international reading and literacy study: South African children's reading literacy achievement, Centre for Evaluation and Assessment, University of Pretoria, Pretoria.

Hussin, A.A., 2018, 'Education 4.0 made simple: Ideas for teaching', International Journal of Education \& Literacy Studies 6(3), 92-98. https://doi.org/10.7575/aiac. ijels.v.6n.3p.92

Jabbour, A.B., Jabbour, C.J., Foropon, C. \& Filho, M.G., 2018, 'When titans meet - Can industry 4.0 revolutions the environmentally sustainable manufacturing wave? The role of critical success factors', Technological Forecasting \& Social Change 132(2018), 18-25. https://doi.org/10.1016/j.techfore.2018.01.017

Khagram, S., 2020, 'How the coronavirus pandemic accelerates the 4th Industrial Revolution', News Wise, 24 April 2020, viewed 07 May 2020, from https://www. newswise.com/coronavirus/how-coronavirus-pandemic-accelerates-thetechnology-of-the-4th-industrial-revolution-https-eiuperspectives-economistcomfinancial-serviceswhy-coronavirus-will-accelerate-fourth-industrial-revolution4 ir/?article_id $=730580$.

Knudsen, M.S. \& Kaivo-oja, J., 2018, Are we in the midst of a Fourth Industrial Revolution? New industry 4.0 insights from future technology analysis professionals, viewed 18 May 2019, from https://ffrc.wordpress.com/2018/08/20/ are-we-in-the-midst-of-a-fourth-industrial-revolution/.

Le, T.T., Andreadakis, Z., Kumar, A., Román, R.G., Tollefsen, S., Saville, M. et al., 2020, 'The COVID-19 vaccine development landscape', Nature Reviews Drug Discovery 19(2020), 305-306. https://doi.org/10.1038/d41573-020-00073-5

Lorenz, M., Rüßmann, M., Waldner, M., Engel, P., Harnisch, M. \& Justus, J., 2015 Industry 4.0: The future of productivity and growth in manufacturing industries, viewed 20 January 2021, from https://www.bcg.com/publications/2015/ engineered_products_project_business_industry_4_future_productivity growth_manufacturing_industries.

Lu, Y., 2017, Cyber Physical System (CPS)-based industry 4.0: A survey', Journal of Industrial Integration and Management 2(3), 1750014. https://doi.org/10.1142/ S2424862217500142

Mafolo, K., Mbovane, T., Damba-Hendrik, N. \& Ngubane, N., 2020, 'Protests over unpaid NSFAS allowances stop education across SA', News24, 10 March, viewed 24 March 2020, from https://www.news24.com/SouthAfrica/News/protests24 March 2020, from https://www.news24.com/SouthAfrica/N
over-unpaid-nsfas-allowances-stop-education-across-sa-20200310.

Marr, B., 2018, '7 job skills of the future (that Als and robots can't do better than humans)', Forbes, 06 August, viewed 06 April 2020, from https://www.forbes. com/sites/bernardmarr/2018/08/06/7-job-skills-of-the-future-that-ais-androm/sites/bernardmarr/2018/08/06/7-job-skills-ont-do-better-than-humans/\#3cf852e86c2e.

Massachusetts Institute of Technology (MIT), 2019a, MIT facts, viewed 07 May 2019, from https://web.mit.edu/facts/faqs.html.

Massachusetts Institute of Technology (MIT), 2019b, General institute requirement viewed 07 May 2019, from https://mitadmissions.org/discover/the-miteducation/general-institute-requirements/.

Massachusetts Institute of Technology (MIT), 2019c, MIT course catalogue bulletin 2018/2019, volume 154, number 1, viewed 07 May 2019, from http://catalog.mit. edu/archive/mit-bulletin-18-19.pdf.

Massachusetts Institute of Technology (MIT), 2019d, Degree chart, viewed 08 May 2019, from http://catalog.mit.edu/degree-charts/computer-science-economics-datascience-course-6-14/computer-science-economics-data-science-course-6-14.pdf.

Mathiba, G., 2020 'Covid-19 and South African universities: A raft of problems to ponder', Maverick Insider, 09 April, viewed 06 June 2020, from https://www. dailymaverick.co.za/opinionista/2020-04-09-covid-19-and-south-africanuniversities-a-raft-of-problems-to-ponder/\#gsc.tab=0.

Mbolekwa, S.A., 2020, 'Covid-19: Universities consider reconfiguring academic year to match that of northern hemisphere', TimesLive, 06 April, viewed 06 April 2020, from https://www.timeslive.co.za/news/south-africa/2020-04-06-covid-19--universities consider-reconfiguring-academic-year-to-match-that-of-northern-hemisphere/.

Menon, K. \& Castrillon, G., 2019, "Universities have "pivotal role" to play in Fourth Industrial Revolution', Daily Maverick, 15 April 2019, viewed 23 May 2019, from https://www.dailymaverick.co.za/article/2019-04-15-universities-have-pivotalrole-to-play-in-fourth-industrial-revolution/. 
Mohamedbhai, G., 2020, 'COVID-19: What consequences for higher education?', World News, Africa edn., 09 April, viewed 07 May 2020, from https://www. World News, Africa edn., 09 April, viewed 07 May 2020, from
universityworldnews.com/post.php?story $=20200407064850279$.

Morse, J.M., Olson, K. \& Spiers, J., 2002, 'Verification strategies for establishing reliability and validity in qualitative research', International Journal of Qualitative Methods 1(2), 13-22. https://doi.org/10.1177/160940690200100202

Mosconi, F., 2015, The new European industrial policy: Global competitiveness and the manufacturing renaissance, Routledge, New York.

Mouton, N., Louw, G.P. \& Strydom, G., 2013, 'Critical challenges of the South African school system', International Business \& Economics Research Journal 12(1), 31-44. https://doi.org/10.19030/iber.v12i1.7510

Ning, H. \& Liu, H., 2015, 'Cyber-physical-social-thinking space based science and technology framework for the Internet of things', Science China Information Sciences 58, 1-19. https://doi.org/10.1007/s11432-014-5209-2

Oczkowskia, S.J.W., Centofantia, J.E., Dureposb, P., Arseneaud, E., Kelecevicb, J., Cook D.J. et al., 2018, 'Organ donation in the ICU: A document analysis of institutional policies, protocols, and order sets', Intensive and Critical Care Nursing 45(2018), 58-65. https://doi.org/10.1016/j.iccn.2017.12.005

Oxford University, 2019a, Online open programmes, Saïd Business School, viewed 28 April 2019, from https://www.sbs.ox.ac.uk/online-open-programmes.

Oxford University, 2019b, Core courses and electives, Saïd Business School, viewed 28 April 2019, from https://www.sbs.ox.ac.uk/programmes/oxford-mba/ academic-curriculum/core-courses-and-electives.

Pandor, N., 2019, 2019 national skills authority conference, Department of Highe Education and Training, viewed 22 May 2019, from https://www.gov.za/speeches/ minister-naledi-pandor-opens-national-skills-conference-and-officiates-skillsawards-gala.

Panikar, P., Dev, S. \& Washington, A., 2015, 'Best practices in curriculum developmen \& delivery with special reference to Educational \& Professional Development Department at Caledonian College of Engineering, Oman', International Journal of Education and Research 3(4), 357-368.

Penprase, B.E., 2018, 'The Fourth Industrial Revolution and higher education', in N. Gleason (eds.), Higher education in the era of the Fourth Industrial Revolution, Palgrave Macmillan, Singapore.

QS, 2019, World university rankings, viewed 25 May 2019, from https://www. topuniversities.com/university-rankings/world-university-rankings/2019.

Rodney-Gumede, Y., 2019, 'South Africa needs to think differently and embrace 4IR', Mail and Guardian, 08 March 2019, viewed 23 May 2019, from https://mg co.za/article/2019-03-08-00-south-africa-needs-to-think-differently-andembrace-4ir.

Sahu, P., 2020, 'Closure of universities due to Coronavirus Disease 2019 (COVID-19): Impact on education and mental health of students and academic staff', Cureus 12(4), 1-7. https://doi.org/10.7759/cureus.7541

Schwab, K., 2016, The Fourth Industrial Revolution: What it means, how to respond, viewed 20 June 2019, from https://www.weforum.org/agenda/2016/01/thefourth-industrial-revolution-what-it-means-and-how-to-respond/.

Shahroom, A.A. \& Hussin, N., 2018, 'Industrial revolution 4.0 and education', International Journal of Academic Research in Business and Social Sciences 8(9), 314-319. https://doi.org/10.6007/IJARBSS/v8-i9/4593

Stanford University, 2019a, Academic programs: Overview, viewed 25 May 2019, from https://admission.stanford.edu/academics/programs/index.html.

Stanford University, 2019b, Academic programs: Degree options, viewed 25 May 2019, from https://admission.stanford.edu/academics/programs/degree_ options.html.

Stanford University, 2019c, Undergraduate degrees and programs, viewed 25 May 2019, from https://exploredegrees.stanford.edu/undergraduatedegreesandprogr ams/\#gerstext.

Stanford University, 2019d, Stanford bulletin explore courses, viewed 25 May 2019, from https://explorecourses.stanford.edu/search?view=catalog\&filtercoursestatus-Active =on \&page $=0 \&$ catalog $=\& q=E C O N \% 20152 \% 3 \mathrm{~A} \% 20$ coursestatus - Active $=$ on $\&$ page $=0 \&$ catalog
The $\% 20$ Future $\% 20$ of $\% 20$ Finance $\&$ collapse $=$.

Stanford University, 2019e, Graduate School of Business, viewed 25 May 2019, from https://www.gsb.stanford.edu/programs/mba/academic-experience/ curriculum/first-year-curriculum.

Stanford University, 2019f, The Stanford Institute for Human-Centred Artificial Intelligence, viewed 20 May 2019, from https://hai.stanford.edu/.
Starman, A.B., 2013, 'The case study as a type of qualitative research', Journal of Contemporary Educational Studies 1, 28-43.

Suskie, L., 2018, Assessing student learning: A common sense guide, 3rd edn., Wiley, San Francisco, CA.

Tamrat, W. \& Teferra, D., 2020, 'COVID-19 poses a serious threat to higher education' University World News, Africa edn., 19 April, viewed 07 May 2020, from https:// www.universityworldnews.com/post.php?story $=20200409103755715$.

The Presidency, 2019a, President Cyril Ramaphosa: State of the Nation Address 2019, viewed 07 January 2020, from https://www.gov.za/speeches/president-cyrilramaphosa-2019-state-nation-address-7-feb-2019-0000.

The Presidency, 2019b, President Cyril Ramaphosa announces reconfigured departments, viewed 07 January 2020, from https://www.gov.za/speeches/ president-cyril-ramaphosa-announces-reconfigured-departments-14jun-2019-0000.

The Presidency, 2019c, President Cyril Ramaphosa: State of the Nation Address 2019, viewed 07 January 2020, from https://www.gov.za/speeches/2SONA2019.

Thomas, D.R., 2006, 'A general inductive approach for analyzing qualitative evaluation data', American Journal of Evaluation 27(2), 237-246. https://doi. org/10.1177/1098214005283748

Times Higher Education (THE), 2020, Educating despite the COVID-19 outbreak: Lessons from Singapore, viewed 20 March 2020, from https://www. timeshighereducation.com/blog/educating-despite-covid-19-outbreak-lessonsSingapore.

University of Cape Town, 2018a, Faculty of commerce (undergraduate), viewed 19 April 2019, from http://www.studyabroad.uct.ac.za/sites/default/files/image tool/images/422/academicinfo/2018_SCI_Handbook.pdf.

University of Cape Town, 2018b, Curriculum change framework, Curriculum Change Working Group, June 2, viewed 07 January 2020, from https://www.news.uct. ac.za/images/userfiles/downloads/media/UCT-Curriculum-Change-Framework. pdf.

University of the Free State, 2020, New flagship degree, viewed 06 April 2020, from https://www.ufs.ac.za/docs/librariesprovider23/landing-page-of-ems/newdegree.pdf?sfursn=af458721_2.

University of Johannesburg, 2019, College of Business and Economics-undergraduate yearbook, viewed 22 April 2019, from https://www.uj.ac.za/faculties/cbe/.

University of Pretoria, 2019, Faculty of Economic and Management Sciences Academic Programmes, Pretoria, viewed 16 April 2019, from https://www.up. ac.za/faculty-of-economic-and-management-sciences/article/2596558/ ac.za/faculty-of-econo
prospective-students.

University of Stellenbosch, 2019, Faculty of Economic and Management Sciences: Academic programmes and faculty information, viewed 16 April 2019, from http://stbweb01.stb.sun.ac.za/university/jaarboek/2013/2013_WEB_EMS.pdf.

University of the Witwatersrand, 2019, 'Commerce, law and management, rules and syllabuses', Johannesburg, viewed 17 April 2019, from https://www.wits.ac.za/ media/wits-university/students/academic-matters/documents/2018\%20Scl\%20 Rules $\% 20$ Syllabuses $\% 20-\% 20$ reduced $\% 20$ size.pdf.

Venkat, H. \& Spaull, N., 2015, 'What do we know about primary teachers' mathematical content knowledge in South Africa? An analysis of SACMEQ 2007', International Journal of Educational Development 41, 121-130.

Watson, G.R. \& Sottile, J., 2010, 'Cheating in the digital age: Do students cheat more in online courses?', Online Journal of Distance Learning Administration 13(1), 1-14.

World Economic Forum (WEF), 2016, The future of jobs: Employment, skills and workforce strategy for the Fourth Industrial Revolution, viewed 17 July 2019, from https://www.weforum.org/agenda/2016/01/the-future-of-jobs/.

World Economic Forum (WEF), 2017, The global competitiveness report, 2017-2018, viewed 28 April 2019, from https://www.weforum.org/reports/the-globalcompetitiveness-report-2017-2018.

World Economic Forum (WEF), 2018, These are the jobs robots can't do, viewed 22 May 2019, from https://www.weforum.org/agenda/2019/05/robo-apocalypsenot-in-your-lifetime/.

Xing, B. \& Marwala, T., 2017, 'Implications of the fourth industrial age for higher education', The Thinker 73, 6 pages.

Xu, L.D., Xu, E.L. \& Li, L., 2018, 'Industry 4.0: State of the art and future trends', International Journal of Production Research 56(8), 2941-2946. https://doi.org/1 $0.1080 / 00207543.2018 .1444806$ 